\title{
OPTIMALISASI PRODUKSI USAHATANI SAYURAN HIDROPONIK DI USAHA HYDRO GARDEN PADANG
}

\section{Production Optimazation Hydroponic Vegetable Farming in Hydro Garden Padang Business}

\author{
Gusma Winda ${ }^{1}$, Vonny Indah Mutiara ${ }^{2}$, Rina Sari ${ }^{2}$ \\ ${ }^{1}$ Ma hasiswa Program Studi Agribisnis Fakultas Pertanian Universitas Andalas, Pa dang, 25163 \\ ${ }^{2}$ Staff Pengajar Program Studi Agribisnis Fa kultas Pertanian Universitas Andalas, Pa dang, 25163 \\ *email koresponden: gusmawinda02@gmail.com
}

\begin{abstract}
Abstrak
Penelitian ini bertujuan untuk menganalisis ketersediaan faktor produksi dan optimalisaasi produksi pada usaha sayu ran hidroponik diHy dro Garden Padang. Penelitia n menggunakan metode studi kasus, dengan respondennya a dalah pe milik usaha dan tenaga kerja yang dijadikan sebagai informan kunci. Analisis da ta menggunakan model program linear dengan bantuan program komputerLINDO (Linier Interactive Descrete Optimizer). Ha sil penelitian m enunjukkan H y dro Garden Padang membudidayakan lima jenis sa yuran yaitu pakcoy, basil, kailan, romain dan arugula. Input -input produksi yang digunakan dalam kegiatan produksi digolongkan menjadi dua. Input produksi tetap yang digunakan memiliki u m u r ekonomi 5 tahun sampai 10 tahun. Sedangkan input produksi variabel tidak terdapat permasalahan dalam hal ketersediaannya sehingga proses produksi dapat berjalan dengan la ncar. Hasilpengolahan da ta m enu nju kkan bahwa keuntungan yang diperoleh pada kondisi optimal yaitu sebesar Rp 6.358.493 dengan memproduksi pakcoy sebanyak 52,5 $\mathrm{kg}$, kailan sebanyak $19 \mathrm{~kg}$, romain sebanyak $178,125 \mathrm{~kg}$ da n arugula sebanyak $95 \mathrm{~kg}$. Hasil a nalisis du al m enun juk kan bahwa yang termasuk kendala sumberdaya terbatas adalah lahan, benih basil, benih romain, dan benih a rugula. Jik a terja di kenaikan ketersediaan sumberdaya tersebut sebesar satu sa tuan maka akan meningkatkan keuntungan sebesar nila i dual pricenya. Analisis sensitivitas terbagi menjadi dua, yaitu analisis sensitivitas koefisien fungsi tujuan dan analisis sensitivita s nilai rua s kanan kendala. Hasil a nalisis sensitivitas menunjukkan nilai penin gkatan maksimum dan nila i penurunan maksimum yang masih diperbolehkan agar hasil kondisi optimal tidak mengalami perubahan.
\end{abstract}

Kata kunci: optimalisa si produksi, progra m linear, sa yur hidroponik

\begin{abstract}
This study aimed to analyze the availabilityproductionfactors and production optimization of hydroponic ve getable business in Hydro Garden Padang. This research used case study method with business owner and workforce respondents as a key informant. Data analysis used linear programming model with support of LINDO (Linier Interactive Descrete Optimizer. The research found that in Hydro Garden Padang cultivate five types of vegetables namely pakcoy, basil, kailan, romain and arugula. Production inputs used in production activities could be classified into two types. Fixed production input which is used has an economical age of 5 years to 10 years. While variable production input does not have a problem. The results of processing data showed that profits in optimal condition Rp 6.358 .493 by producing 52,5 $\mathrm{kg}$ of pakcoy, $19 \mathrm{~kg}$ of kailan, $178,125 \mathrm{~kg}$ of romain, and $95 \mathrm{~kg}$ of arugula. The results of dual analysis showed that was included as a limited resource constraints wereland, basil seed, romain seed, and arugula seed. When the resource availabilityincreased, it wouldalso increase profits by the value ofdual price. Sensitivity analysis was divided into two types which were sensitivity analysis of objective function coefficients and sensitivityanalysis of right hand sideconstraint value. The results of sensitivity analysis showed that maximum increa se value and maximum decrease value was still allowed so that the results ofoptimal conditions didnotchange.
\end{abstract}

Keywords: production optimization, linear programming, hydroponic vegetable 


\section{PENDAHULUAN}

Salah satu komoditas pertanian yang berpotensi untuk dikembangkan yaitu komoditas hortikultura, sayuran merupakan salah satu komoditas holtikultura yang memegang peranan penting dalam pemenuhan kebutuhan manusia khususnya dalam hal kecukupan pangan dan gizi yang dibutuhkan, karena sayuran merupakan salah satu sumber mineral dan vitamin yang dibutuhkan manusia. Sayuran merupakan sumber vitamin A, B1, dan C, di samping itu sayuran juga mengandung beberapa mineral seperti kalsium (Ca) dan besi (Fe) (Muchtadi \& Sugiyono, 1992).

Meningkatnya populasi penduduk, kesejahteraan masyarakat, serta pengetahuan masyarakat akan kesehatan maka akan berpengaruh terhadap peningkatan permintaan sayuran sehingga produksi sayuran harus ditingkatkan. Peningkatan kuantitas dan kualitas produksi sayuran juga sangat perlu dilakukan pada masa sekarang, mengingat produk sayuran yang mudah rusak dan voluminous. Selain itu, kesadaran konsumen dalam memilih produk yang akan dikonsumsi juga dapat menjadi tantangan bagi produsen hortikultura (Poerwanto \& Susila, 2014). Sebagai solusi permasalahan tersebut, manusia secara kreatif telah mengembangkan berbagai teknologi untuk memproduksi tanaman sayuran, buah, dan tanaman hias tanpa menggunakan tanah dengan jumlah air yang sedikit. Teknologi ini dikenal dengan nama hidroponik (Poerwanto \& Susila, 2014).

Salah satu usaha yang bergerak di bidang budidaya sayuran hidroponik yaitu Hydro Garden Padang. Hydro Garden Padang merupakan suatu usaha yang didirikan pada tahun 2014 dan mulai beroperasi pada awal tahun 2015. Berdasarkan survey pendahuluan diketahui bahwa pihak Hydro Garden hanya menggunakan perkiraan permintaan dalam menentukan jenis sayuran yang akan ditanam sehingga pada saat-saat tertentu terjadi kelebihan produksi untuk satu jenis tanaman dan pada waktu yang lain terjadi kekurangan stok untuk jenis sayuran lain. selain itu, jenis sayuran yang dibudidayakan sangat banyak, pihak Hydro Garden sendiri juga ingin memfokuskan ke beberapa jenis sayuran saja sehingga masalah ini harus dicarikan pemecahannya melalui penelitian ilmiah.

Dari bermacam-macam jenis sayuran yang diusahakan di Hydro Garden Padang dapat dibuat beberapa alternatif, pemilik usaha akan memilih satu alternatif jenis sayuran apa yang akan diusahakannya. Dalam pemilihan alternatif ini pemilik usaha akan dihadapkan pada masalah keterbatasan sumberdaya yang tersedia diantaranya adalah terbatasnya jumlah lobang tanam yang akan diusahakan, terbatasnya jumlah tenaga kerja yang tersedia dan terbatasnya jumlah modal yang akan digunakan serta terbatasnya jumlah benih yang tersedia. Dengan adanya keterbatasan sumberdaya tersebut, maka untuk pengujian statistik dilakukan dengan menggunakan metode linear programming. Persoalan programming, pada dasarnya berkenaan dengan penentuan alokasi yang optimal dari pada sumber-sumber langka (limited resources) untuk memenuhi tujuan (objective). Misalnya seperti tenaga kerja, material, mesin, tanah, pupuk, air sehingga diperoleh output yang maksimum (Supranto, 1983).

Pendekatan program linier cocok diaplikasikan di usaha Hydro Garden Padang. Secara teknis seluruh kebutuhan analisis dapat dipenuhi seperti kombinasi jenis sayuran yang dibudidayakan, jumlah lubang tanam yang tersedia, bibit, nutrisi, dan tenaga kerja. Selain itu peningkatan keuntungan usaha sangat diharapkan. Oleh sebab itu keputusan tentang kombinasi jenis sayuran berdasarkan luas lahan yang tersedia perlu dibuat. Apakah akan membudidayakan salah satu atau kombinasi dari berbagai jenis sayuran supaya dapat memberikan keuntungan yang maksimal dengan memperhitungkan keterbatasanketerbatasan yang ada. Dari penjelasan tersebut, maka kajian tentang optimalisasi usahatani sayuran hidroponik menjadi sangat diperlukan. 
Berdasarkan rumusan masalah diatas, maka tujuan dari penelitian ini adalah sebagai berikut :

1. Menganalisis ketersediaan faktor produksi pada usaha sayuran hidroponik di Hydro Garden Padang

2. Menganalisis optimalisasi produksi sayuran hidroponik di Hydro Garden Padang

\section{METODE PENELITIAN}

Penelitian dilaksanakan di Hydro Garden Padang, yang berlokasi di Jalan Kampung Nias VI No. 60 Padang, Sumatera Barat. Pemilihan lokasi dilakukan dengan sengaja (purposive). Penelitian ini dilaksanakan pada bulan Maret 2020 - April 2020. Penelitian dilaksanakan dengan menggunakan metode deskriptif, adapun jenis metode deskriptif yang digunakan dalam penelitian ini adalah metode studi kasus (case study). Metode pengambilan responden yaitu secara sensus., responden yang diambil sebanyak dua orang yaitu pemilik usaha Hydro Garden dan karyawannya yang berjumlah satu orang yang dijadikan informan kunci untuk mengumpulkan data mengenai usaha hidroponik tersebut dan membantu dalam pengumpulan informasi serta data yang dibutuhkan untuk menjawab permasalahan penelitian.

Untuk tujuan pertama yaitu menganalisis ketersediaan input-input produksi pada usaha sayuran hidroponik di Hydro Garden Padang, variabel yang diamati yaitu input produksi tetap dan input produksi variabel. Untuk tujuan kedua yaitu menganalisis optimasi usaha sayuran hidroponik di Hydro Garden Padang, variabel yang diamati yaitu harga jual sayuran hidroponik, jumlah produksi sayuran yang dihasilkan, biaya, penerimaan, keuntungan, variabel yang diamati untuk merumuskan fungsi kendala (X) (terdiri dari lahan (jumlah lubang tanam), modal, tenaga kerja, benih), variabel yang diukur untuk merumuskan fungsi tujuan (Y) (keuntungan yang diperoleh untuk masing-masing jenis komoditas sayuran yang dibudidayakan).

Analisis data yang digunakan untuk tujuan pertama adalah analisis kualitatif, analisis ini digunakan agar dapat menguraikan keadaan yang sebenarnya mengenai ketersediaan input-input produksi pada usaha sayuran hidroponik di Hydro Garden Padang. Untuk tujuan kedua, analisis data yang digunakan adalah analisis kuantitatif. Analisis ini digunakan untuk mengetahui biaya dan pendapatan usaha sayuran hidroponik di Hydro Garden Padang dan juga untuk melakukan analisis optimalisasi, analisis primal, analisis dual dan analisis sensitivitas.

\section{a. Penerimaan}

Penerimaan adalah perkalian antara produksi yang diperoleh dengan harga jual (Soekartawi, 1995). Dapat dirumuskan sebagai berikut:

$T R i=Y i x P y i$

Keterangan:

$\mathrm{TRi}=$ total penerimaan masing-masing jenis sayuran

Yi $=$ jumlah produksi sayuran hidroponik masingmasing jenis sayuran

Pyi = harga jual masing-masing jenis sayuran

\section{b. Keuntungan}

Keuntungan adalah selisih antara penerimaan dengan biaya total. Biaya total adalah seluruh biaya yang digunakan dalam proses produksi pada periode waktu tertentu (Soekartawi, 1995).

$\pi i=T R i-T C i$

Keterangan:

$\pi=$ keuntungan masing-masing jenis sayuran

$\mathrm{TR}=$ total penerimaan masing-masing jenis sayuran

$\mathrm{TC}=$ total biaya masing-masing jenis sayuran

c. Biaya Total

Biaya total adalah penjumlahan biaya tetap dan biaya variable (Soekartawi, 1995).

$T C=F C+V C$

Keterangan:

$\mathrm{TC}=$ Biaya total

$\mathrm{FC}=$ Biaya Tetap / Fixed Cost

VC = Biaya Variabel / Variable Cost 


\section{d. Biaya Penyusutan}

Besarnya biaya penyusutan dapat dihitung dengan menggunakan metode garis lurus. Metode ini digunakan dengan pemikiran bahwa benda yang dipakai dalam pengolahan menyusut dalam besaran setiap tahunnya (Subanar, 1994).

$D=(P-S) / N$

Keterangan:

$\mathrm{D}=$ besarnya penyusutan $(\mathrm{Rp} / 45$ hari $)$

$\mathrm{P}=$ harga beli (Rp)

$\mathrm{S}=$ nilai sisa $(\mathrm{Rp})$

$\mathrm{N}=$ umur ekonomis (thn)

Untuk menganalisis optimasi usahatani sayuran hidroponik di Hydro Garden Padang menggunakan metode analisis linear programming menurut (Aminudin, 2005). Model ini sudah disesuaikan dengan kebutuhan penelitian, yaitu sebagai berikut :

Fungsi tujuan

Maks $\mathrm{Z}=\pi 1+\pi 2+\pi 3+\pi 4+\pi 5$

Keterangan:

Maks Z : Keuntungan maksimum dari kombinasi optimal beberapa Jenis Sayuran

$\pi 1$ : keuntungan sayuran pakcoy $(\mathrm{Rp} / \mathrm{kg})$

$\pi 2$ : keuntungan sayuran basil $(\mathrm{Rp} / \mathrm{kg})$

$\pi 3$ : keuntungan sayuran kailan $(\mathrm{Rp} / \mathrm{kg})$

$\pi 4$ : keuntungan sayuran romain $(\mathrm{Rp} / \mathrm{kg})$

$\pi 5$ : keuntungan sayuran arugula $(\mathrm{Rp} / \mathrm{kg})$

Kendala Lahan (jumlah lubang tanam)

$L 1+L 2+L 3+L 4+L 5 \leq b 1$

Keterangan:

L1 : Luas lahan yang digunakan untuk sayuran pakcoy (lubang tanam/kg)

L2 : Luas lahan yang digunakan untuk sayuran basil (lubang tanam/kg)
L3 : Luas lahan yang digunakan untuk sayuran kailan (lubang tanam $/ \mathrm{kg}$ )

L4 : Luas lahan yang digunakan untuk sayuran romain(lubang tanam $/ \mathrm{kg}$ )

L5 : Luas lahan yang digunakan untuk sayuran arugula (lubang tanam $/ \mathrm{kg}$ )

b1 : Batas ketersediaan lahan

Kendala Modal

$M 1+M 2+M 3+M 4+M 5 \leq b 2$

Keterangan:

M1 : Jumlah Modal yang dibutuhkan untuk sayuran pakcoy $(\mathrm{Rp} / \mathrm{kg})$

M2 : Jumlah Modal yang dibutuhkan untuk sayuran basil ( $\mathrm{Rp} / \mathrm{kg})$

M3 : Jumlah Modal yang dibutuhkan untuk sayuran kailan $(\mathrm{Rp} / \mathrm{kg})$

M4 : Jumlah Modal yang dibutuhkan untuk sayuran romain $(\mathrm{Rp} / \mathrm{kg})$

M5 : Jumlah Modal yang dibutuhkan untuk sayuran arugula $(\mathrm{Rp} / \mathrm{kg})$

b2 : Batas ketersediaan modal

Kendala Tenaga Kerja

$T K 1+T K 2+T K 3+T K 4+T K 5 \leq b 3$

Keterangan:

TK1 : Jumlah HOK yang digunakan untuk sayuran pakcoy $(\mathrm{jam} / \mathrm{kg})$

TK2 : Jumlah HOK yang digunakan untuk sayuran basil (jam/kg)

TK3 : Jumlah HOK yang digunakan untuk sayuran kailan $(\mathrm{jam} / \mathrm{kg})$

TK4 : Jumlah HOK yang digunakan untuk sayuran romain $(\mathrm{jam} / \mathrm{kg})$

TK5 : Jumlah HOK yang digunakan untuk sayuran arugula $(\mathrm{jam} / \mathrm{kg})$ 
b3 : Batas ketersediaan tenaga kerja

Kendala benih

$\mathrm{B} 1 \leq \mathrm{b} 4.1$

$\mathrm{B} 2 \leq \mathrm{b} 4.2$

$\mathrm{B} 3 \leq \mathrm{b} 4.3$

$\mathrm{B} 4 \leq \mathrm{b} 4.4$

B5 $\leq$ b4.5

Keterangan:

B1 : Jumlah benih yang dibutuhkan untuk sayuran pakcoy

B2 : Jumlah benih yang dibutuhkan untuk sayuran basil

B3 : Jumlah benih yang dibutuhkan untuk sayuran kailan

B4 : Jumlah benih yang dibutuhkan untuk sayuran romain

B5 : Jumlah benih yang dibutuhkan untuk sayuran arugula

b4.1 : Batas ketersediaan bibit sayuran pakcoy

b4.2 : Batas ketersediaan bibit sayuran basil

b4.3 : Batas ketersediaan bibit sayuran kailan

b4.4 : Batas ketersediaan bibit sayuran romain

b4.5 : Batas ketersediaan bibit sayuran arugula

Fungsi tujuan dan fungsi kendala yang telah disusun selanjutnya diolah dengan bantuan program komputer LINDO (Linier Interactive Descrete Optimizer).

\section{HASIL DAN PEMBAHASAN}

\section{Profil Usaha Sayuran Hidroponik Hydro Garden Padang}

Hydro Garden Padang merupakan sebuah usaha yang bergerak di bidang budidaya sayuran hidroponik yang didirikan oleh bapak Yohanes De Brito Dedy Putranto, Usaha ini didirikan pada tahun 2014 dan mulai beroperasi pada awal tahun 2015. Hydro Garden Padang beralamat di Jalan Kampung
Nias VI No. 60, Kelurahan Ranah Parak Rumbio, Kecamatan Padang Selatan, Kota Padang, Sumatera Barat. Usaha hidroponik ini memiliki satu orang karyawan yang bekerja di bagian produksi, sedangkan bagian pemasaran di lakukan oleh bapak Dedy selaku pemilik usaha, selain itu untuk peracikan nutrisi dilakukan sendiri oleh bapak Dedi.

Sistem budidaya yang digunakan adalah Nutrient Film Technique (NFT). Konsep dasar sistem NFT ini adalah akar tanaman yang dibudidayakan tumbuh pada lapisan nutrisi yang dangkal dan tersirkulasi sehingga tanaman dapat memperoleh cukup air, nutrisi, dan oksigen. Air yang mengandung semua nutrisi terlarut tersebut diberikan secara terusmenerus selama 24 jam. Tujuan akhir dari sistem ini adalah memperoleh panen yang berkualitas.

Sayuran di Hydro Garden Padang di jual dalam bentuk kemasan dan dapat juga dalam satuan kilogram, harga untuk satu kemasan yaitu Rp.10.000,- sedangkan jika dijual dalam satuan kilogram harganya berbeda-beda tergantung jenis sayuran, pakcoy dijual dengan harga Rp.35.000/kg,-, basil dijual dengan harga Rp.100.000/kg,-, kailan dijual dengan harga Rp.45.000/kg,-, romain dijual dengan harga Rp.40.000/kg,- dan arugula dijual dengan harga Rp.45.000/kg,-. Untuk tempat pemasarannya, Hydro Garden Padang sudah memiliki konsumen tetap. Sebagian besar konsumen tersebut dari golongan menengah keatas, karena dilihat dari harga sayuran hidroponik yang lebih mahal dibandingkan harga sayuran konvensional di pasar tradisional. Hydro Garden Padang memasarkan hasil produksinya ke resort, Pusat Buah Metro, Kuali Nyonya Cafe, Foodmart, Pondok Saudara, Weekend Cafe dan beberapa cafe lainnya yang ada di Kota Padang serta ibu rumah tangga yang berada di sekitar lokasi usaha.

\section{Ketersediaan Input-input Produksi}

Ketersediaan input- input produksi yang digunakan dalam kegiatan produksi di Hydro Garden Padang secara garis besar dapat digolongkan menjadi dua, yaitu input produksi tetap dan input produksi variabel. 


\section{Input produksi tetap}

Input produksi tetap terdiri dari peralatan produksi, lahan dan bangunan. Peralatan yang digunakan dalam proses produksi diantaranya pipa paralon, mesin pompa, bak nutrisi (drum), paranet, cok cabang, nampan, netpot, dan pelobang busa. Peralatan ini secara umum memiliki umur ekonomi 5 tahun sampai 10 tahun, pada saat dilakukan penelitian peralatan yang digunakan masih layak pakai karena masih dalam umur ekonomis. Untuk lebih jelasnya berikut uraian dari masing-masing input produksi tetap yang digunakan oleh Hydro Garden Padang.

1. Pipa paralon, mesin pompa dan bak nutrisi

Pipa paralon, mesin pompa dan bak nutrisi disebut juga dengan sarana irigasi. Mesin pompa digunakan untuk mengalirkan air dan nutrisi yang berasal dari bak nutrisi, larutan nutrisi tersebut dialirkan ke tanaman melalui pipa paralon.

\section{Paranet}

Paranet adalah jala plastik yang umumnya digunakan untuk memberi naungan bagi tanaman budidaya. Paranet ini berfungsi untuk mengurangi intensitas cahaya yang diterima tumbuhan serta untuk mengurangi suhu udara disekitar tumbuhan.

\section{Cok cabang}

Cok cabang merupakan sarana untuk mengalirkan listrik karena yang membutuhkan listrik tidak hanya satu sehingga dibutuhkan cok cabang untuk memudahkan dalam pembagian listrik.

\section{Nampan}

Nampan merupakan media yang digunakan untuk pembibitan sayuran hidroponik. Nampan yang digunakan oleh Hydro Garden Padang memiliki ukuran $30 \mathrm{~cm}$ x $40 \mathrm{~cm}$.

5. Netpot
Netpot merupakan tempat untuk meletakkan busa yang berisi sayuran hidroponik yang siap untuk pembesaran.

\section{Pelobang busa}

Pelobang busa merupakan alat yang digunakan untuk mempermudah dalam membuat lubang semai benih, sekali tusuk bisa membuat 30 lubang.

\section{Lahan}

Lahan yang digunakan oleh Hydro Garden Padang untuk membudidayakan sayuran hidroponik merupakan lahan sewa yang berlokasi di Jalan Kampung Nias VI No. 60, Kelurahan Ranah Parak Rumbio, Kecamatan Padang Selatan, Kota Padang, Sumatera Barat. Lahan ini memiliki luas $\pm 250 \mathrm{~m}^{2}$. Dari luas lahan tersebut tersebut terdiri dari satu bangunan untuk menyimpan alat dan bahan yang dibutuhkan dalam kegiatan budidaya sayuran hidroponik, sedangkan untuk tempat budidaya sayuran hidroponik tersebut terdiri dari 8 rak meja, setiap meja memiliki jumlah pipa yang bervariasi antara 15 - 19 pipa, satu pipa memiliki 25 lobang tanam sehingga total lubang tanam yang tersedia di Hydro Garden Padang yaitu sebanyak 3.375 lobang tanam.

\section{Input produksi variabel}

Input produksi variabel yang digunakan oleh Hydro Garden Padang dalam budidaya sayuran hidroponik antara lain benih, nutrisi, rockwool, listrik dan air, plastik packing dan stiker, dan biaya tenaga kerja.

\section{Benih}

Benih merupakan salah satu sarana produksi yang sangat penting dalam usaha budidaya sayuran hidroponik karena benih yang berkualitas akan menghasilkan sayuran yang berkualitas juga. Pada saat penelitian, sayuran yang sedang dibudidayakan ada 5 macam yaitu pakcoy, basil, kailan, romain dan arugula. Untuk satu kali musim tanam, benih yang tersedia yaitu lima bungkus untuk setiap jenis sayuran yang akan dibudidayakan, lima bungkus 
benih tersebut dapat digunakan semuanya dan dapat juga digunakan untuk beberapa kali musim tanam tergantung berapa banyak sayur yang ingin diproduksi dan jumlah lobang tanam yang tersedia.

\section{Nutrisi}

Dalam hidroponik, istilah pupuk disebut nutrisi. Nutrisi hidroponik adalah pupuk hidroponik lengkap yang mengandung semua unsur hara makro dan mikro yang diperlukan tanaman hidroponik. Nutrisi yang digunakan oleh pihak Hydro Garden Padang adalah nutrisi ABmix, nutrisi ini diramu sendiri oleh pemilik usaha dengan alasan kebutuhannya secara terus-menerus sehingga jika diramu sendiri biaya nutrisi menjadi lebih hemat, selain itu nutrisi hidroponik yang sudah jadi dan siap pakai jarang dijual di pasaran.

\section{Rockwool}

Media yang digunakan untuk budidaya sayuran hidroponik ialah rockwool. Rockwool terbuat dari batu apung yang dipanaskan dan dibentuk serat serta wafer dengan spesifikasi khusus untuk tanaman sayuran maupun tanaman hias. Rockwool memiliki kemampuan menahan air dan udara dalam jumlah banyak sehingga baik untuk mendukung perkembangan akar tanaman. Rockwool berfungsi untuk penyemaian benih dan tempat tumbuhnya sayuran hidroponik.

\section{Listrik dan air}

Dalam budidaya sayuran hidroponik listrik dan air merupakan hal yang penting, listrik digunakan untuk menghidupkan mesin air dan juga sebagai penerangan, akan tetapi sayuran Hydro Garden Padang sudah mendapakan cahaya matahari yang cukup sehingga tidak memerlukan tambahan penerangan pada malam hari, sedangkan air merupakan media dalam budidaya sayuran hidroponik.

\section{Plastik packing dan stiker}

Plastik packing merupakan kemasan yang digunakan Hydro Garden Padang untuk memasarkan produknya dan stiker berfungsi sebagai media promosi dalam menjalankan usaha sayuran hidroponik. Terdapat dua jenis plastik yang berbeda yang digunakan untuk pengemasan sayuran hidroponik tersebut yaitu plastik bening (plastik kaca) yang digunakan untuk pengemasan sayur yang akan diantar ke pusat buah dan yang kedua yaitu kantong plastik kresek yang biasanya digunakan untuk menjual sayuran kepada konsumen langsung dan pesanan dari cafe-cafe di Kota Padang.

\section{Tenaga Kerja}

Dalam usaha budidaya sayuran hidroponik penggunaan tenaga kerja tidak dibutuhkan dalam jumlah yang banyak namun cukup dengan beberapa orang yang mempunyai keahlian dan kemampuan dibidang sistem hidroponik. Dalam kegiatan usaha budidaya sayuran hidroponik sistem NFT di Hydro Garden Padang, tenaga kerja berjumlah 2 orang tenaga kerja pria. Satu orang bertugas dibagian budidaya yang bekerja 8 jam sehari selama enam hari dalam seminggu. Sedangkan untuk bagian peracikan

Tabel 1. Total biaya produksi usaha sayuran Hydro Garden Padang satu kali musim tanam

\begin{tabular}{llc}
\hline No & Uraian & Biaya total \\
\hline 1 & Sewa lahan & $1.875 .000,00$ \\
2 & Benih & $700.000,00$ \\
3 & Nutrisi & $600.000,00$ \\
4 & Rockwool & $333.333,00$ \\
5 & Listrik dan air & $750.000,00$ \\
6 & Plastik packing dan stiker & $100.000,00$ \\
7 & Tenaga Kerja & $3.375 .000,00$ \\
8 & Penyusutan Alat & $1.341 .918,75$ \\
\hline 9 & TotalBiaya & $9.075 .251,75$ \\
\hline
\end{tabular}


nutrisi dan pemasaran dilakukan oleh bapak Dedy selaku pemilik usaha yang bekerja 4 jam sehari selama enam hari dalam seminggu. Tenaga kerja tersebut digaji sebesar Rp.1.500.000,- perbulan untuk jam kerja 8 jam perhari

\section{Biaya}

Dalam usaha sayuran hidroponik di Hydro Garden Padang biaya yang dihitung yaitu biaya produksi selama satu kali musim tanam yakni pada bulan 01 Maret 2020 - 14 April 2020. Untuk lebih jelasnya dapat dilihat pada Tabel 1 .

Biaya untuk masing-masing jenis sayuran yang sedang diusahakan dapat dilihat pada Tabel 2

\section{Perumusan Model Linier Optimalisasi}

Koefisien fungsi tujuan ditentukan oleh besarnya keuntungan dari setiap jenis sayuran yang dibudidayakan. Koefisian fungsi tujuan pada penelitian ini adalah dengan menghitung keuntungan per kg masing-masing jenis sayuran yang sedang di budidayakan pada musim tanam Maret 2020 - April 2020. Keuntungan masing-masing jenis sayuran dapat dilihat pada Tabel 3. Berdasarkan pada Tabel 3 tersebut maka fungsi tujuan linear programming model optimalisasi produksi usahatani sayuran hidroponik di HydroGarden Padang dapat dirumuskan sebagai berikut:

$\operatorname{Max} Z=10.064,06 x 1+32.697,94 \times 2+$

Tabel 2. Biaya produksi masing-masing jenis sayuran di Hydro Garden Padang satu kali musim tanam (Rupiah/kg)

\begin{tabular}{lrrrrr}
\hline \multirow{2}{*}{ Uraian } & \multicolumn{5}{c}{ Biaya per kg produksi (Rp/kg) } \\
\cline { 2 - 6 } & \multicolumn{1}{c}{ Pakcoy } & \multicolumn{1}{c}{ Basil } & \multicolumn{1}{c}{ Kailan } & \multicolumn{1}{c}{ Romain } & \multicolumn{1}{c}{ Arugula } \\
\hline Sewa lahan & $5.555,56$ & $13.888,89$ & $8.333,33$ & $4.444,44$ & $5.555,56$ \\
Benih & 147,37 & 5263,16 & 789,47 & 982,46 & $1.315,79$ \\
Nutrisi & $1.777,78$ & $4.444,44$ & $2.666,67$ & $1.422,22$ & $1.777,78$ \\
Rockwool & 987,65 & $2.469,13$ & $1.481,48$ & 790,12 & 987,65 \\
Listrik dan air & $2.222,22$ & $5.555,56$ & $3.333,33$ & $1.777,78$ & $2.222,22$ \\
Plastik packing dan stiker & 269,30 & 740,74 & 444,44 & 237,04 & 269,30 \\
Upah TK & $10.000,00$ & $25.000,00$ & $15.000,00$ & $8.000,00$ & $10.000,00$ \\
Penyusutan Alat & $3.976,06$ & $9.940,14$ & $5.964,08$ & $3.180,84$ & $3.976,06$ \\
\hline TotalBiaya & $24.935,94$ & $67.302,06$ & $38.012,80$ & $20.834,90$ & $26.104,36$ \\
\hline
\end{tabular}

\section{Penerimaan dan Keuntungan}

Dalam penelitian ini, penerimaan dan keuntungan yang dihitung adalah penerimaan dan keuntungan untuk satu kilogram produksi masing-masing jenis sayuran. Untuk lebih jelasnya dapat dilihat pada Tabel 3
$6.987,20 \times 3+19.165,10 \times 4+18.895,64 \times 5 \ldots(1)$

Selain fungsi tujuan, untuk memenuhi kriteria persamaan dalam analisis program linear juga diperlukan persamaan fungsi kendala. Kendala merupakan pembatas untuk mengambil sebuah keputusan. Kendala yang digunakan dalam

Tabel 3. Penerimaan dan keuntungan usaha sayuran Hydro Garden Padang pada musim tanam 01 Maret 2020 - 14 April 2020 (Rupiah/kg)

\begin{tabular}{lrrrrr}
\hline Sayuran & Biaya total & Harga Jual/kg & Penerimaan/Kg & Keuntungan/kg & Keuntungan \% \\
\hline Pakcoy & $24.935,94$ & 35.000 & 35.000 & $10.064,06$ & 40,36 \\
Basil & $67.302,06$ & 100.000 & 100.000 & $32.697,94$ & 32,70 \\
Kailan & $38.012,80$ & 45.000 & 45.000 & $6.987,20$ & 18,38 \\
Romain & $20.834,90$ & 40.000 & 40.000 & $19.165,10$ & 91,99 \\
Arugula & $26.104,36$ & 45.000 & 45.000 & $18.895,64$ & 72,38 \\
\hline
\end{tabular}


penyelesaian optimalisasi ini meliputi (1) kendala lahan, (2) kendala tenaga kerja, (3) kendala modal, dan (4) kendala benih.

Kendala lahan (jumlah lubang tanam) :

$10 x 1+25 x 2+15 x 3+8 x 4+10 x 5 \leq 3.375$

Kendala modal :

$24.935,94 x 1+67.302,06 x 2+38.012,80 x 3+$ $20.834,90 \times 4+26.104,36 \times 5 \leq 9.075 .251,75$

Kendala tenaga kerja :

$1,35 x 1+3,38 x 2+2,02 x 3+1,08 x 4$

$+1,35 \times 5 \leq 456$

Kendala bibit :

$10 \times 1 \leq 11.875$

$25 \times 2 \leq 475$

$15 \times 3 \leq 2.375$

$8 \times 4 \leq 1.425$

$10 \times 5 \leq 950$

\section{Hasil Analisis Optimalisasi Produksi}

\section{Analisis Primal}

Berdasarkan perhitungan dengan menggunakan program LINDO didapatkan nilai optimalisasi sayuran hidroponik yang dihitung dari fungsi tujuan sebesar Rp.6.358.493,-, hasil ini dapat dicapai jika mengusahakan sayuran pakcoy sebanyak $52,5 \mathrm{~kg}$, basil sebanyak $19 \mathrm{~kg}$, romain sebanyak $178,125 \mathrm{~kg}$ dan arugula sebanyak $95 \mathrm{~kg}$. Sedangkan pada kondisi aktual (musim tanam periode Maret-April 2020) perusahaan memperoleh keuntungan sebesar Rp.4.617.659,45,-. Perbedaan keuntungan yang diperoleh perusahaan antara kondisi optimal dengan kondisi aktual (Musim Tanam Periode Maret-April 2020) adalah Rp.1.740.834,-. Keuntungan optimal yang diperoleh meningkat sebanyak $37,7 \%$ dari keuntungan aktual yang diperoleh perusahaan, hal ini berarti dalam kondisi optimal keuntungan perusahaan masih dapat ditingkatkan sebesar 37,7\% dari keuntungan kondisi aktual. Peningkatan keuntungan ini disebabkan karena perubahan jumlah jenis sayuran yang diproduksi dari kondisi aktual.

\section{Analisis Dual}

Berdasarkan hasil analisis dual price nya, yang termasuk kedalam kendala sumberdaya terbatas adalah sumberdaya lahan, benih basil, romain, dan arugula. Jika terjadi kenaikan ketersediaan sumberdaya sebesar satu satuan akan meningkatkan nilai fungsi tujuan sebesar nilai dual pricenya. Sedangkan yang termasuk sumberdaya tidak aktif atau berlebih yaitu modal, tenaga kerja, benih pakcoy dan kailan, dimana apabila terjadi penambahan atau pengurangan sumberdaya tersebut tidak akan mengurangi nilai pada fungsi tujuan.

\section{Analisis Sensitivitas}

Hasil analisis sensitivitas menunjukkan bahwa jika salah satu harga sayuran dirubah dalam rentang yang ditunjukkan oleh batas peningkatan dan batas penurunan sesuai dengan Objective Coefficient Ranges maka tidak akan merubah tingkat produksi optimal, tetapi hanya merubah nilai dari fungsi tujuan.

Begitu juga dengan sensitivitas masing-masing variabel,. Untuk variabel lahan, benih basil, romain dan arugula, tingkat produksi optimal tidak akan berubah apabila kenaikan dan penurunan ketersediaan sumberdaya tidak melebihi batas sensitivitasnya. Untuk variabel modal, tenaga kerja, benih pakcoy dan kailan memiliki batas kenaikan infinity (tidak terbatas), hal ini menunjukkan bahwa apabila sumberdaya mengalami kenaikan dari nilai original valuenya naik sampai tak terhingga maka sumberdaya tersebut tidak akan mempengaruhi keuntungan maksimal karena penambahan satu satuan sumberdaya tidak menambah nilai keuntungan maksimal sebesar nilai dual valuenya. Penambahan yang terjadi akan mengalami kelebihan ketersediaan sehingga adanya sumberdaya yang tidak digunakan. 


\section{KESIMPULAN}

Berdasarkan hasil penelitian tentang optimalisasi produksi usahatani sayuran hidroponik di usaha Hydro Garden Padang dapat diambil kesimpulan bahwa usaha hidroponik di Hydro Garden Padang membudidayakan lima jenis sayuran yaitu pakcoy, basil, kailan, romain dan arugula. Input-input produksi yang digunakan dalam kegiatan produksi secara garis besar dapat digolongkan menjadi dua, yaitu input produksi tetap dan input produksi variabel. Input produksi tetap yang digunakan secara umum memiliki umur ekonomi 5 tahun sampai 10 tahun, pada saat dilakukan penelitian peralatan yang digunakan masih layak pakai karena masih dalam umur ekonomis. Sedangkan untuk input produksi variabel tidak mengalami permasalahan dalam hal ketersediaannya sehingga proses produksi dapat berjalan dengan lancar.

Usaha Hydro Garden Padang yang bergerak dalam bidang sayuran hidroponik belum berproduksi secara optimal, kombinasi pola tanam lima jenis sayuran pada kondisi aktual mengalami perubahan pola tanam menjadi empat jenis sayuran pada kondisi optimal, disamping itu terjadi peningkatan pada kuantitas sayuran hidroponik yaitu jumlah produksi sayur pada kondisi aktual sebesar $317,125 \mathrm{~kg}$ mengalami peningkatan menjadi $344,625 \mathrm{~kg}$ pada kondisi optimal. Keuntungan yang diperoleh perusahaan pada kondisi optimal yaitu sebesar Rp.6.358.49,-3, sedangkan pada kondisi aktual perusahaan memperoleh keuntungan sebesar Rp.4.617.659,45,-. Keuntungan yang diperoleh pada kondisi optimal ini mengalami kenaikan sebanyak $37,7 \%$ dari keuntungan aktual yang diperoleh perusahaan. Hal ini disebabkan karena perubahan jumlah jenis sayuran yang diproduksi dari kondisi aktual dimana usaha Hydro Garden Padang yang optimal yaitu jika membudidayakan 52,5 kg pakcoy, $19 \mathrm{~kg}$ basil, $178,125 \mathrm{~kg}$ romain dan $95 \mathrm{~kg}$ arugula.

\section{UCAPAN TERIMA KASIH}

Ucapan terima kasih kepada pembimbing Dosen Prodi Agribisnis yang selalu mendukung penulis selama pelaksanaan penelitian dan penulisan skripsi.

\section{DAFTAR PUSTAKA}

Aminudin. (2005). Prinsip-Prinsip Riset Operasi. Jakarta: Erlangga.

Muchtadi, T. R., \& Sugiyono. (1992). Ilmu Pengetahuan Bahan Pangan. Bogor: Petunjuk Laboratoriu m PAU IPB.

Poerwanto, \& Susila. (2014). Teknologi Hortikultura. Bogor: PT penerbit IPB Press.

Soekartawi. (1995). Analisis usahatani. Jakarta: Gramedia pustaka utama.

Subanar,H. (1994). Manajemen Usaha Kecil. Yogyakarta: BPFE Universita s Gajag Mada.

Supranto, J. (1983). Linear Programming edisi kedua. Jakarta: Fakultas Ekonomi Universitas Indonesia. 